\title{
ACCOUNTING PEDAGOGY BASED ON EXTANT AUTHORITATIVE RULES VERSUS DECISION-ORIENTED ANALYSIS: THE CASE OF OTHER POSTEMPLOYMENT BENEFITS
}

\author{
David W. Wright \\ UNIVERSITY OF MICHIGAN
}

\begin{abstract}
Contemporary financial accounting pedagogy has been criticized for its excessive concentration on extant authoritative rules and preparer-oriented mechanics. An alternative decision-oriented pedagogy would emphasize the economic consequences of financial accounting choices, analyze the role of accounting information within a broader economic, legal and political context, and consider emerging issues that remain authoritatively unresolved. This article illustrates a decision-oriented accounting pedagogy for the treatment of the other postemployment benefits (OPEB) issues. This article has two primary objectives. First, it provides a source for relevant economic, legal, and accounting background information and a set of decision-oriented, conceptually-motivated cases and topics for class discussion. Second, it uses the OPEB topic to illustrate the general pedagogic principle of addressing accounting issues from a decision-oriented rather than a preparer-oriented perspective. This approach could be equally useful for the treatment of a variety of accounting related topics, including asset reversions from defined benefit pension plan terminations and curtailments, corporate restructurings and downsizings, or employee stock options and deferred compensation agreements.
\end{abstract}

Recently, accounting educators have been criticized in both academic and professional quarters for their excessive concentration on extant accounting practices and authoritative rules to the exclusion of a more decision-oriented analysis. In lieu of a rule-dominated pedagogy, a number of broader objectives have been proposed, including developing:

1. An understanding of the role of accounting information in the financial markets and managerial decision making (American Accounting Association, 1986);

2. An ability to exercise conceptually oriented reasoning in addressing "unresolved" and ambiguous situations (Courtis, 1987; Subotnik, 1987);

3. An appreciation of the complexity of issues facing the profession toward the end of producing leaders in the profession who might play a role in improving and advancing the discipline itself (Zeff, 1989).

The author gratefully acknowledges the useful comments of Eugene Imhoff, Jr., Jeffery Abarbanell, participants at the 1989 Michigan/Ontario Finance and Accounting Conference and the 1990 American Accounting Association Western Regional Meeting, two anonymous reviewers, and the Associate Editor, David Stout. Financial support was provided by the University of Michigan School of Business Administration. 
Inman, Wenzler, \& Wickert (1989) provide evidence that the rule-dominated pedagogy contributes to the often asserted "Brain Drain" of students from accounting to other disciplines. Their survey of students transferring out of accounting to another field of concentration produced the following comments (p. 38):

- "Accounting is just memorization. You don't really have to analyze that much ... It really [turned me off]."

- "Finance courses ... relate to what's going on in the world. The stock market . . . has an effect on day-to-day life."

In offering a prescription for improved accounting education pedagogy, the chairmen of each of the (then) "Big Eight" firms jointly recommended (Kullberg, Gladstone, Scanlon, Cook, Groves, Horner, O’Malley, \& Kangas, 1989):

- "Accounting knowledge cannot focus solely on the construction of data ... Accountants must be able to use the data, exercise judgments, evaluate risks and solve real-world problems. Passing the CPA examination should not be the goal of accounting education. The focus should be on developing analytical and conceptual thinking - versus memorizing rapidly expanding professional standards." (p. 8)

- "The current textbook-based, rule-intensive, lecture/problem style should not survive as the primary means of presentation." (p. 11)

Symptomatic of the traditional rule-oriented pedagogy traditionally followed in accounting education is the style and content of accounting textbooks. Zeff (1989, pp. 203-204) observes:

Beginning with the textbook for the first financial accounting course and continuing through the intermediate and advanced accounting textbooks, the subject is offered as if a catalogue of practice were being inputted into computer memory. ... Typically, a problem facing the profession's practitioners is asserted (not argued), the official solution is exposited, journal entries and sample financial statements illustrating the official solution are presented, and the students are then put through the hoops of numerical problems that test their capacity to apply the official solution to hypothetical situations.

Perhaps nowhere is the issue of textbook concentration on extant authoritative pronouncements more clearly illustrated than in the area of employer accounting for other postemployment benefits (OPEBs). ${ }^{1}$ OPEBs have

These benefits consist primarily of a continuation of medical care and/or life insurance coverage for the employee and often the employee's dependents. Numerous authors refer to these benefits as postretirement benefits. However, it has been noted to me that postretirement 
emerged as one of the most contentious issues facing, among others, the Financial Accounting Standards Board (FASB), Congress, the courts, employers, employees and their bargaining agents, and the health-care delivery system. After years of study, the FASB has proposed one of its most controversial standards to date-Employers' Accounting for Postretirement Benefits Other Than Pensions (FASB, 1989). ${ }^{2}$ Numerous unresolved court cases and pending Congressional legislation debate employers' rights and obligations regarding benefit funding and vesting requirements and options for the tax deductibility of prefunding contributions. Articles appear regularly in the financial press about these issues. Yet despite the controversy and attention surrounding OPEBs, coverage of the topic in the current cditions of leading intermediate financial accounting textbooks ranges from scant to nil. ${ }^{3}$

This article provides an overview of the current economic, legal and accounting issues surrounding other postemployment benefits as a source for relevant material that may be useful in integrating the topic into the accounting curriculum. It is not the purpose of this article to fully explore the numerous issues surrounding OPEB accounting nor to propose any "official" solutions to the problems in an attempt to resolve the ambiguities about the topic in the student's mind. Rather, in the spirit of AAA (1986), Subotnik (1987), and Zeff (1989), the objective is simply to frame the accounting issues within some of the broader legal, economic and political forces at play in the OPEB controversy. This is done in an effort to expose students to the background of an important developing issue which currently occupies so much attention by the authoritative boards, corporate management, the judiciary, the legislature, and the financial press. As a result, through the specific example of OPEB accounting, students may gain a

implies death and the more appropriate terminology should be postemployment benefits. In point of fact, SFAS No. 81 (FASB, 1984, fn. 1) makes a distinction between the terminology postretirement and postemployment, which is not maintained in this paper.

2In perhaps the understatement of the decade, Dennis Beresford, chairman of the FASB, was quoted as saying: "Some companies won't be terribly happy with what we have done. (Freudenheim, 1988, p. D6)"

3Six intermediate financial accounting textbooks were reviewed for their coverage of OPEB topics. These were Chasteen, Flaherty, and O'Connor (1989); Kieso and Weygandt (1989); Mosich (1989); Nikolai and Bazley (1988); Welsch and Zlatkovich (1989); and Williams, Stanga, and Holder (1989). These texts range in length from 1,320 to 1,486 pages. The greatest attention given to OPEB topics was less than two pages, with one text not discussing the topic at all. It should be noted that the accounting controversy over OPEBs is ncither ncw nor newly discovered. The FASB originally included the issue of OPEB accounting in its recently completed pension project as a major component of its first Discussion Memorandum (FASB, 1981). Gewirtz, Green, \& Napoli, Jr. (1982) is an early yet remarkably contemporary description of the issues surrounding OPEB accounting. 
basis for understanding the multiple economic, political, social, and ethical dimensions of a major contemporary accounting issue.

The remainder of the article is organized into five sections. The first section outlines the continuing development of accounting standards for OPEB costs. Sections two and three summarize some of the important economic and legal issues surrounding OPEBs. Section four speculates on future events and Section five suggests several topics for class discussion and/or student projects that may be useful in motivating and structuring the presentation of the material in the preceding sections.

\section{HISTORICAL AND PROPOSED ACCOUNTING TREATMENT OF OPEB COSTS}

In beginning its extensive pensions project, the FASB announced that accounting for OPEB costs would be a component of the overall project. The original Discussion Memorandum (FASB, 1981) solicited respondents' views on whether OPEB accounting should be consistent with that of defined benefit pension plans. The FASB's preliminary views on OPEB accounting favored accrual of the costs (FASB, 1982, par. 131):

The cost of retirees' health care and life insurance benefits should be accrued during the service lives of employees who are expected to receive those benefits, provided the amounts involved are material. Pay-as-you-go (cash basis) and terminal funding (accrue at retirement) methods would not be acceptable methods for recognizing such costs in accrual-basis financial statements.

The initial FASB Discussion Memorandum (FASB, 1983) affirmed the concept of OPEB accrual accounting and asked respondents to discuss specific features of transition, attribution period definition, and so on. However, on February 18, 1984, the progression toward OPEB accrual accounting was slowed as the FASB announced the separation of OPEB accounting from the pensions project with the initiation of a separate agenda item.

The issuance of SFAS No. 81 (FASB, 1984) required certain additional disclosures about OPEB costs, but allowed the continuation of pay-as-yougo cash basis accounting. Required disclosures included a description of benefits and covered employee groups, a description of funding and accounting policies, and the annual cost of OPEB benefits for retirees, if readily separable from the total cost for active employees and retirees.

SFAS No. 87 (FASB, 1985a) applies only to defined benefit pension plans and not to other postemployment health and life insurance benefits. However, footnote 3 of the standard again referred to a separate agenda item for OPEBs and stated that SFAS No. 87 did not proscribe nor discourage accrual of OPEB costs. Thus, in 1987 a technical bulletin was issued (FASB, 1987a) further describing the employer's option to adopt accrual accounting for OPEB costs. The switch from cash basis accounting can be made either prospectively or currently (through a charge to income of the cumulative 
effect of the change as of the first day of the fiscal year). No guidance is given on the length of the "transition period" to be used if the prospective method is employed.

On February 14, 1989, the FASB issued a major Exposure Draft of a proposed standard on accounting for OPEB costs. The following summarizes the major provisions of the proposal.

- Accrual accounting for OPEB plans would be required in a manner very similar to the accounting for defined benefit pension plans under SFAS No. 87.

- The proposed expense is comprised of six components:

1. Service cost, which assigns the ultimate liability to years of employee service from the date of hire through the date full benefit eligibility is achieved. An alternative, longer attribution period would have assigned costs over a period extending until the employee's expected retirement date.

2. Interest cost on the accumulated postretirement benefit obligation.

3. Actual return on plan assets (if any).

4. Amortization of unrecognized prior service cost from benefits retroactively granted at the time of plan initiation or amendment.

5. Actuarial gains and losses to the extent they exceed a corridor.

6. Amortization over at most 15 years of the unrecognized net obligation existing at the date of adoption of the new standard. ${ }^{4}$

- Three sources of unrecognized off-balance sheet amounts will remain, requiring a footnote reconciliation of the plan's actual status to the financial statement representation of the plan:

1. Unrecognized actuarial gains and losses.

2. Unrecognized prior service costs.

3. Unrecognized net transition obligation existing at the date of adoption of the new standard.

- Disclosure requirements:

Significant assumptions, including health care cost trend rate.

The effect of a one percent change in the health care cost trend rate.

Reconciliation of plan status to financial statement position.

Components of OPEB expense.

- A minimum liability (with any supplemental liability offset by an intangible asset) would be required for any excess of the accumulated postretirement benefit obligation (for retirees and fully eligible active employees only) over plan assets.

\footnotetext{
4Subsequent to the issuance of the Exposure Draft, the FASB publicly announced two tentative changes in its proposed treatment of this transition amount. These changes would allow employers the option of immediate recognition of the entire transition amount at the date the standard is initially adopted or delayed recognition over a 20 -year period, rather than the 15 year period initially proposed in the Exposure Draft.
} 
A recently completed field test sponsored by the Financial Executives Research Foundation studied the financial statement effects of the FASB proposal on 26 companies. The results showed that for the majority of companies in the survey OPEB expenses would increase two to six times from their current level under the proposal and the implied off-balance sheet (and currently undisclosed) liability would comprise over $10 \%$ of shareholders' equity (Coopers \& Lybrand, 1989). Table 1 summarizes some of the results of the field test.

As illustrated in Table 1, the income statement impact will tend to be greatest for companies with a higher proportion of active employees relative to current retirees. In part, this is because of the fact that under the current pay-as-you-go accounting, no OPEB expense is being recognized for active employees whereas the cash basis expense for retirees may not be grossly below the accrual expense (interest and transition amortization).

The findings of the Coopers and Lybrand study are consistent with earlier estimates. Business Week reported that the OPEB expense would increase roughly fourfold for mature companies and by a factor of 8 to 12 for companies with a younger work force and few retirees (Norman, 1988). Thomas Nelson, a consulting actuary with Milliman and Robertson, estimates the accrual expense to be two to five times higher than the cash basis (Miller, 1988). Richard Poccia, a partner with Coopers and Lybrand, estimated the increase to be three to six times for mature companies and up to 20 times for companies with an immature workforce (Ness, 1989). Moreover, in most circumstances under SFAS No. 96 (FASB, 1987b) the full pretax effect will flow through to net income due to the inability of the company to record a deferred tax asset from OPEB expenses (Coopers \& Lybrand, 1989).

To put these estimates into perspective, consider General Motors Corporation, which reported net income (before the cumulative effects of an unrelated accounting change) of $\$ 4.6$ and $\$ 3.6$ billion in 1988 and 1987 , respectively. The OPEB pay-as-you-go expenses for those years were $\$ 1.1$ and $\$ 1.0$

\section{Table 1. Estimated effects of the FASB OPEB exposure draft on 26 surveyed companies (Coopers \& Lybrand, 1989)}

\begin{tabular}{lcc}
\hline \multirow{2}{*}{$\begin{array}{l}\text { Number of Times Accrual Expense } \\
\text { Exceeds Pay-As-You-Go Expense }\end{array}$} & \multicolumn{2}{c}{ Number of Companies } \\
\cline { 2 - 3 } & $\begin{array}{c}\text { Mature } \\
\text { Companies }\end{array}$ & $\begin{array}{c}\text { Immature } \\
\text { Companies }\end{array}$ \\
\hline Less than 2 times & 2 & - \\
2.0 to 3.9 times & 7 & - \\
4.0 to 5.9 times & 9 & 1 \\
Greater than 6 times & 4 & 3 \\
\hline
\end{tabular}


billion. Thus, a fourfold increase in the OPEB expense with no offsetting tax benefit under SFAS No. 96 would have effectively eliminated GM's entire net income for those two years. William Reimert, a consulting actuary with Milliman and Robertson, estimates that had the proposed rule been in effect, 125 of the 500 largest industrial companies would have reported losses in 1987 (Freudenheim, 1988). Presumably, this impact would persist over the 15-year transition period. The following remarks were made by Chrysler Corporation's Chief Financial Officer during FASB public hearings:

We have estimated the annual earnings effect will add $\$ 1.2$ billion to our costs, wiping out three-fourths of our 1988 profits before tax. Moreover, the balance sheet liability will grow to over $\$ 13$ billion by the year 2000 , if we live that long. That's twice our current net worth. This isn't just a technical adjustment to our statements. This is accounting Armageddon for us. (Miller, 1989)

\section{SIGNIFICANT ECONOMIC ASPECTS}

This section outlines some of the current significant economic aspects of other postemployment benefit coverage. Because, in part, of the lack of uniform comprehensive disclosure about corporate OPEB obligations, much of the data reported in this section is based on the results of surveys and estimates by knowledgeable experts in the field. ${ }^{5}$

A Charles D. Spencer \& Associates survey of 100 corporate annual reports indicates that $80 \%$ of the sample companies disclosed some costs associated with OPEB coverage (Taplin, 1988). ${ }^{6}$ Large firms (Coopers \& Lybrand and Hewitt Associates, 1985, and Schellhardt, 1989) and those in certain industries (predominantly the traditional "smokestack" and laborintensive enterprises [Cron, Kintzele, \& Kintzele, 1988; Parker, 1988; and Taplin, 1988]) are more likely to offer OPEB coverage.

Because employers are not legally obligated nor, in general, encouraged through the benefits of a tax deduction (discussed below) to prefund, most OPEBs are unfunded. Thus, benefits are typically "funded" by the employer on a "pay-as-you-go basis" (i.e., when premiums are due to the insurer for the retiree coverage or when claims are incurred by retirees if the company is acting as the insurer itself).

Despite the growing awareness by management and its employee benefits

\footnotetext{
5Students may be asked to consider the difficulties faced by accounting and legislative regulators in assessing the cost/benefit trade-offs of new requirements in the presence of such a sparsity of "hard" data.

6Statistics cited in this article are referenced in numerous articles in the popular financial press. An intentional effort has been made to cite references from a broad spectrum of business publications rather than relying more heavily on traditional accounting publications. This was done in an effort to illustrate the cross-functional characteristics of the OPEB issue and to illustrate the attention given to proposed accounting standards in the business media at large.
} 
consultants of the size of the OPEB obligations and their drain on corporate earnings and cash flows, demographic and medical care cost and utilization trends have combined to force OPEB costs increasingly higher each year. A Charles D. Spencer \& Associates survey of 100 corporate annual reports indicates that of those companies disclosing OPEB coverage, $80 \%$ reported higher costs in 1987 than in 1986 (Taplin, 1988). For the 12 months ended June 1989, the Consumer Price Index rose 5.2\% while the medical care cost component rose $7.5 \%$-continuing a trend of medical care costs rising at a rate greater than or equal to the economywide inflation rate in 31 of the last 36 years (U.S. Department of Labor, 1989). Moreover, demographic trends indicate the U.S. population is aging and the life expectancy of retirees is lengthening. Between 1990 and the year 2000 the population over age 50 is expected to rise $18.5 \%$ while the number of Americans under age 50 is predicted to grow by only $3.5 \%$ (Ostroff, 1989). Morcover, the life expectancy of a 65-year-old has increased 2.5 years since 1960 (Greenwald, 1989). These trends will serve to both increase medical care costs and utilizations as well as lengthen the benefit payment period itself.

Estimates on the aggregate unfunded (and predominantly unrecorded and undisclosed) OPEB liability are large and highly variable as illustrated in Table 2. As noted earlier, the wide range of estimates may, in part, be attributable to the lack of "hard" data as a result of the limited disclosure requirements imposed under SFAS No. 81 (FASB, 1984). There is no U.S. government entity analogous to the Pension Benefit Guarantee Corporation insuring these unfunded OPEB benefits.

Recent reports in the financial press indicate many companies are still uncertain about the magnitude of the OPEB obligations they face. Consider, for example, the following excerpts from recent articles appearing in the popular press on the OPEB crisis:?

Table 2. Public estimates of the total OPEB "accrued" liability

\begin{tabular}{lcl}
\hline Source & Date & \multicolumn{1}{c}{ Estimate } \\
\hline U.S. Department of Labor & 1986 & \$98 billion \\
House Select Committee on Aging & 1986 & $\$ 2$ trillion \\
Health Insurance Association of America & 1987 & $\$ 140-350$ billion \\
General Accounting Office & 1988 & $\$ 227$ billion \\
\hline
\end{tabular}

7Further evidence of this lack of knowledge over the magnitude of OPEB liabilities is provided by the following two examples. Several companies were unable to participate in the Coopers $\&$ Lybrand/FERF survey because they could not gather the necessary plan and demographic information in order to perform a retiree health care cost valuation (Cheney, 1989). The leveraged buyout firm Clayton \& Dubilier reported that it would not have taken Uniroyal private had it known of the existence of a $\$ 600$ million unrecorded OPEB liability (Jereski, 1987). 
- A 1988 study of large corporate pension plans by the consulting firm Greenwich Associates . . . reported $90 \%$ of companies have not yet calculated the present value of their retiree medical liability. (Williams, 1989a)

- Indeed, few companies know how big the bill could be. We were absolutely appalled, says FASB project manager Diana J. Scott. They honestly weren't measuring this. In some cases, they didn't even know whom they were covering as dependents. (Norman, 1988)

- "We've done some figuring on the back of an envelope and we don't want to issue any figures right now because we don't want to alarm our investors or employees," says the controller of a major manufacturing company that prefers to remain anonymous. (Berton, 1988)

Companies that offer early retirement incentives as a part of a "downsizing" or corporate reorganization strategy may be subject to large unanticipated OPEB costs. The present value of retiree health benefits for an individual retiring at age 55 has been reported by the actuarial consulting firm Milliman \& Robertson to be potentially twice that for an employee retiring at age 65 ("Corporate Liabilities for Retiree Health Benefits," 1988). Several reasons exist for the higher early-retirement costs (Fluhr, 1989):

- Benefits are payable over a longer period of time.

- Medicare does not share in the cost of health care for retirees under the age of 65 .

- Those workers in poorer health are the ones most likely to select the early retirement option.

- Individuals who are not actively employed are more likely to utilize health care services.

The degree to which the capital markets impound the off-balance sheet liability in firm valuation and lending decisions is difficult to assess. The limited data presented under the required disclosures of SFAS No. 81 make it extremely difficult to estimate the off-balance sheet liability using publicly available data. Numerous assumptions regarding the number and ages of active employees and retirees, their expected retirement age and life expectancy, discount rates, turnover rates and health care inflation rates must be made. With the exception of health care costs, these are essentially the same assumptions necessary for actuarial valuations of defined benefit pension plans under SFAS No. 87 reporting and disclosure requircments. Howcver, other than the discount rate, these assumptions are not required financial statement disclosure items. Thus, within the current reporting environment, the financial statement user must both make and employ numerous assumptions to estimate the firm's existing undisclosed and unrecorded present value of unfunded OPEB costs.

Nonetheless, representatives of Moody's Investors Service, Inc. and Standard \& Poor's Corp. have asserted that they do not expect the FASB propos- 
al for OPEB accrual to have much effect on credit quality because the liabilities are already factored into company ratings (Rudin, 1988). The credibility of this claim, however, is debatable based upon the difficulty of estimating the OPEB liability from public data and the evidence cited above that many companies themselves do not know the magnitude of their own OPEB obligation! Moreover, the Coopers and Lybrand/FERF study of the estimated effects of the proposed accrual accounting standard concluded:

Some companies could fail to meet restrictive covenants in their debt agreements. In addition, some financial analysts may immediately deduct from net income or stockholders' equity the disclosed, but unrecorded, obligation at the date accrual accounting is adopted in evaluating a company's position. (Williams, 1989b)

Nonetheless, most recently the Wall Street Journal reported:

Standard \& Poor's Corp. said if the Financial Accounting Standards Board adopts a proposal to force companies to deduct billions of dollars from profits for retirees' medical benefits, the credit-rating agency will ignore it.

Scott Sprinzen, an assistant vice president for corporate finance for S\&P, said that while medical costs have become an important issue in accounting, adoption by the FASB of its proposal "wouldn't cause any downgradings of corporate debt" by S\&P because of resulting increased liabilities or lower profits...

Mr. Sprinzen said that the FASB's approach is "flawed, due to the highly speculative assumptions that would be necessary." . . S\&P said if the proposal is adopted, S\&P would "reverse the resulting accounting changes." (Berton, 1989a)

Although they haven't gone as far as issuing a precommitment to ignore the accruals, other financial analysts have been critical of the FASB's proposal because of the inherent estimation difficulties. Lee Seidler, a senior managing director of Bear, Stearns \& Co., stated:

No one's been right about guessing health care costs even one year out, let alone decades. So why slam it into the balance sheet? (Norman, 1988)

The New York Times reports that although the financial statement effects of the proposed OPEB accrual accounting may be enormous, some financial analysts feel the effects of the new accounting and disclosure requirements on stock prices will be minimal:

Jeremy Gold, a principal in the pension division of Morgan Stanley \& Company, said concerns about stock values were exaggerated. "The new rules may be something our clients don't particularly want," he said, but the consequences 
"will not be a surprise on Wall Street." In his view, stock prices already reflect a rough estimate of the financial burden. (Freudenheim, 1988)

However, in the same New York Times article, a somewhat more pessimistic view was taken by William Reimert, a consulting actuary at Milliman \& Robertson:

The vast majority of investors have no idea how big the numbers are. . . If earnings decrease by one-third or one-half, that has to have a tremendous impact on stock values. (Freudenheim, 1988)

Moreover, a report by the research and polling firm Sherlock Company found that three-quarters of healthcare analysts surveyed believe equity valuations of companies with large retiree bases would be negatively affected (Cheney, 1989).

The preceding discussion focuses on domestic economic and financial reporting issues surrounding OPEB coverage. These issues are further complicated when placed in the broader context of a global economy. Most foreign countries do not face the issue of employer sponsored postemployment medical care, since these costs are paid by the government under various forms of national health insurance (Coopers \& Lybrand and Hewitt Associates, 1985). Moreover, foreign-owned firms not preparing U.S. GAAP financial statements would not, of course, be subject to OPEB accrual accounting under the FASB's proposed standard.

The information presented in this section highlights both the economic magnitude of the OPEB issue and the controversy over the adequacy and usefulness of the existing and proposed financial accounting reporting and disclosure requirements. Students who recognize both the breadth and magnitude of these economic issues combined with the differences of opinion on the role of accounting information in these circumstances will indeed begin to appreciate the complexity of the issues facing the accounting profession today (Zeff, 1989). The information presented in the following section furthers this process with a consideration of OPEB tax and legal issues.

\section{TAX AND LEGAL ISSUES}

The legal implications surrounding company-sponsored OPEB coverage include three major considerations: (1) income tax treatment of OPEB costs, (2) requirements to continue OPEB coverage once it is initiated, and (3) requirements to prefund OPEB costs.

\section{OPEB Income Tax Treatment}

Under the current tax law, it is difficult for employers to obtain a deduction for "excess OPEB costs" (i.e., those over the current year's cash out- 
lays). Thus, corporate income tax deductions are generally available only on a pay-as-you-go basis. This is one of the major differences between postemployment income benefits (pensions) and other postemployment benefits and is one of the reasons why the vast majority of OPEB plans are unfunded.

There are at least two exceptions to the general rule of nondeductibility of OPEB prefunding (Bazzle, 1989). First, OPEBs can be incorporated into an existing pension plan as an ancillary benefit under Section $401(\mathrm{~h})$ of the Internal Revenue Code. Prefunding would be tax deductible (as for retirement income benefits), but benefits received by retirees would remain tax exempt (unlike retirement income which is taxable). However, the OPEB portion of the benefit package must be "incidental" to the plan-contributing no more than $25 \%$ of the entire contribution. Moreover, because of this constraint, if overall pension contributions are limited or suspended because of plan overfunding, then the allowable deductible contribution for OPEBs can be severely eroded or eliminated. ${ }^{8}$

Alternatively, OPEBs can be funded through the use of a Section $501(\mathrm{c})(9)$ voluntary employee beneficiary association (VEBA). As in a pension plan, employer contributions are tax deductible and the trust fund's investment income, in general, is not taxed. However, deductible funding is limited to the projected cost of benefits at current medical costs and utilization patterns. Thus, projections for medical care inflation and increased utilization rates (which, in general, account for a substantial portion of the OPEB medical care accrued liability) cannot be made in calculating the allowable deduction for the prefunding of OPEB coverage. This is analogous to the tax treatment of retirement income benefits limiting the deduction to service costs based on the Accumulated Benefit Obligation, which is calculated as if the ultimate benefits will be based on current salary levels. This limitation makes the VEBA an insufficient tax-preferred mechanism for prefunding the entire OPEB. Moreover, investment earnings on the VEBA trust may be subject to some taxation under the unrelated business tax provisions of the 1984 Deficit Reduction Act. Nonetheless, VEBAs are an available technique for prefunding at least some of a firm's OPEB costs. American Information Technologies Corporation (Ameritech) recently adopted this approach for funding its OPEB obligation (DiBlase, 1989).

\section{Requirements to Continue OPEB Coverage}

The employer's legal obligation to continue OPEB coverage, once offered, is an unresolved issue at the center of numerous recent and pending court

8However, in a recent Private Letter Ruling, the IRS allowed a deduction for prefunding retiree health care benefits even when contributions to the pension plan have been curtailed because of overfunding, if a set of specific criteria are met (including the use of a particular actuarial cost method) (Greene, 1989). 
cases. In determining the employer's right to terminate or curtail benefits, the courts generally consider three elements ("Courts Look to Reasonable Behavior in Denial Cases," 1989):

1. The terms of the plan.

2. The disclosure, description, and explanation of plan terms to active employees during their working career and at retirement.

3. The past application of plan terms.

In general, in the absence of unambiguous communication before retirement that the company has the right to reduce benefits, the courts have tended to uphold retiree claims for continuation, since there is a justifiable expectation of benefits based on past payment (even in the absence of an explicit contract). However, because of the recency of the termination-rights issue, many important cases are pending or in the appeals process. Moreover, OPEB plan documents frequently are not clear on termination rights and, consequently, in many instances the legal obligation of employers will need to be established on a case-by-case basis (Schmitt, 1988). A summary of some of the more recent rulings on the issue of OPEB terminations and curtailments is given in Table 3 .

In July 1986, LTV Corporation, while in Chapter 11 bankruptcy, announced that it was terminating life and health insurance coverage for its existing retirees. Following a two-week strike by its employees in reaction to the announcement, LTV reversed its decision and reinstated the OPEB coverage. Nonetheless, LTV's attempt to terminate OPEB coverage prompted Congress to consider the issue. In May 1988, the Retiree Benefits Protection Act (100 P.L. 334) was enacted into law, prohibiting termination of OPEB coverage while a company is in Chapter 11 bankruptcy unless its continuation would force liquidation.

\section{OPEB Prefunding Requirements}

The 1974 Employee Retirement Income Security Act, of course, places an obligation on employers to prefund defined benefit retirement income pension plans. Neither pay-as-you-go nor terminal (i.e., at retirement) funding techniques are allowed under the law for retirement income benefits. However, no such law requires employers to prefund OPEB costs. This, combined with the difficulty of obtaining a tax deduction for prefunding, has resulted in the vast majority of OPEB plans being completely unfunded.

\section{EMERGING ISSUES AND POTENTIAL FUTURE DEVELOPMENTS}

Several legislative initiatives are under consideration in Congress related to employer funding of OPEB costs. In April 1989, Representatives Rod Chandler (R-Wash.), and Ronnie Flippo (D-Ala.), and Senator David Pryor 


\section{Table 3. Summary of recent OPEB judicial decisions}

UAW v. Cadillac Malleable Iron Company:

The trial court ruled that Cadillac could not terminate or modify the postemployment medical benefits for existing retirees. The court held that there is a presumption of vesting in the absence of clear evidence to the contrary. On appeal, the Sixth Circuit Court disagreed that an intent to vest should be presumed, but affirmed the lower court's ruling, finding sufficient evidence in this case of the employer's intent to vest.

Bower v. The Bunker Hill Co.:

The courts found that OPEB coverage survives the company's operations. The collective bargaining agreement was silent on the duration of benefits. However, the summary plan description suggested medical benefits would continue as long as the pension benefits.

Metal Polishers Local No. 11 v. Kurz-Kasch, Inc.:

The courts found OPEB benefits were linked to the duration of the collective bargaining agreement, since that agreement specifically stated that all terms and conditions terminated at the end of the contract. A similar ruling was issued in UAW Locals 704 and $1215 \mathrm{~V}$. Roblim Industries, Inc.

Eardman v. Bethlehem Steel Corp.:

Plan documents stated the company had the right to terminate retiree benefits. However, company personnel made oral statements to retiring employees that benefits were for life. Thus, the court upheld retiree claims for the continuation of benefits.

Musto v. American General:

Plan documents indicated the employer had the right to terminate or modify the plan. Other communications were found to be less specific and may have misled certain employees but did not directly contradict the written agreements. Thus, the court upheld the company's right to reduce benefits.

UAW v. Yard-Man, Inc.:

The Sixth Court of Appeals found that retiree benefits are "status benefits" and they carry an inference that they will continue. The court ruled that this inference standing alone is not sufficient to establish an intent to vest interminable benefits, but is a supporting factor to be considered on a case-by-case basis. There was no explicit statement in the collective bargaining agreement that benefits were intended only for the duration of the contract. Thus, the court upheld the claim for continuation of benefits.

Moore v. Metropolitan Life Insurance Co.:

An appeals court ruled the company had the right to reduce benefits despite promises in company newsletters and other publications of "lifetime" benefits "at no cost" and an interim informational pamphlet (issued prior to publication of the final plan documents) which made no mention of the company's right to curtail benefits.

(D-Ark.), introduced bills that would allow employers a tax deduction for prefunding retiree health benefits (Brostoff, 1989). In June 1989, the House Ways and Means Committee began consideration of a proposal that would permit companies to use "excess" funds from overfunded pension plans to prefund OPEB costs (Birnbaum, 1989). The employee benefits consulting firm Greenwich Associates reports that $70 \%$ of pension management executives favor some asset-transfer provision (Williams, 1989a). Representatives Chandler and Flippo have also introduced separate legislation that would prevent employers from terminating overfunded pension plans and taking asset reversions. Under this bill, excess assets could only be used to fund OPEBs (Brostoff, 1989). 
Much continued controversy over the FASB Exposure Draft can be expected. Especially contentious issues include the length of the attribution and transition periods, the inherent "softness" and volatility in the estimates, and the requirement for a minimum liability. Deloitte, Haskins \& Sells proposed in public hearings before the FASB that the transition obligation amortization bypass net income and be charged directly to shareholders' equity as a component of "comprehensive income" as contemplated by the as-yet unused provisions of FASB Concepts Statement No. 5 ("DH\&S Advocates Fresh Start for Postretirement Benefits Accounting," 1989).

Continued litigation and legislation over the rights of companies to terminate or curtail benefits should be expected. In addition, legislation to "ERISAfy" OPEBs, may be considered. This might include required prefunding, required vesting provisions, and the creation of a governmentsponsored guarantee corporation to back underfunded benefits (i.e., "PBGCify" OPEB).

Several companies have begun accruing OPEB costs under FASB Technical Bulletin 87-1. This trend of early adoption of OPEB accrual prior to final passage of a new standard can be anticipated under several theories outlined in Table $4 .{ }^{9}$

\section{TOPICS FOR CLASS DISCUSSION AND STUDENT PROJECTS}

The preceding four sections present a great deal of background information about the legal, economic, and accounting issues surrounding the ongoing controversy over the accounting for OPEB costs. However, if the recommendations for altered accounting pedagogy (AAA, 1986; Kullberg et al., 1989) are to be followed, then this material should not be presented as outlined in a lecture or textbook format and then followed by a series of problems and examinations in which students are asked to recall the specific data. As an alternative, a series of decision-oriented, analytical, and/or conceptually motivated cases, student projects and interactive class discussions can be structured to flesh out the relevant issues and facts.

As students address the issues embodied in the questions, they will inevitably encounter the need for additional background data of the type presented in the preceding sections. In this manner, the questions themselves motivate the relevant issues and "tease out" the factual data surrounding the OPEB topic. Thus, a part of the learning process involves enhancing the student's ability to assess: "What is it I need to know in the way of economic background information to address this question adequately?"

This section offers a few examples of decision-oriented questions atypical of the traditional preparer-oriented "accounting standard recall" questions

${ }^{9}$ For empirical tests of these theories see Wright (1990). 


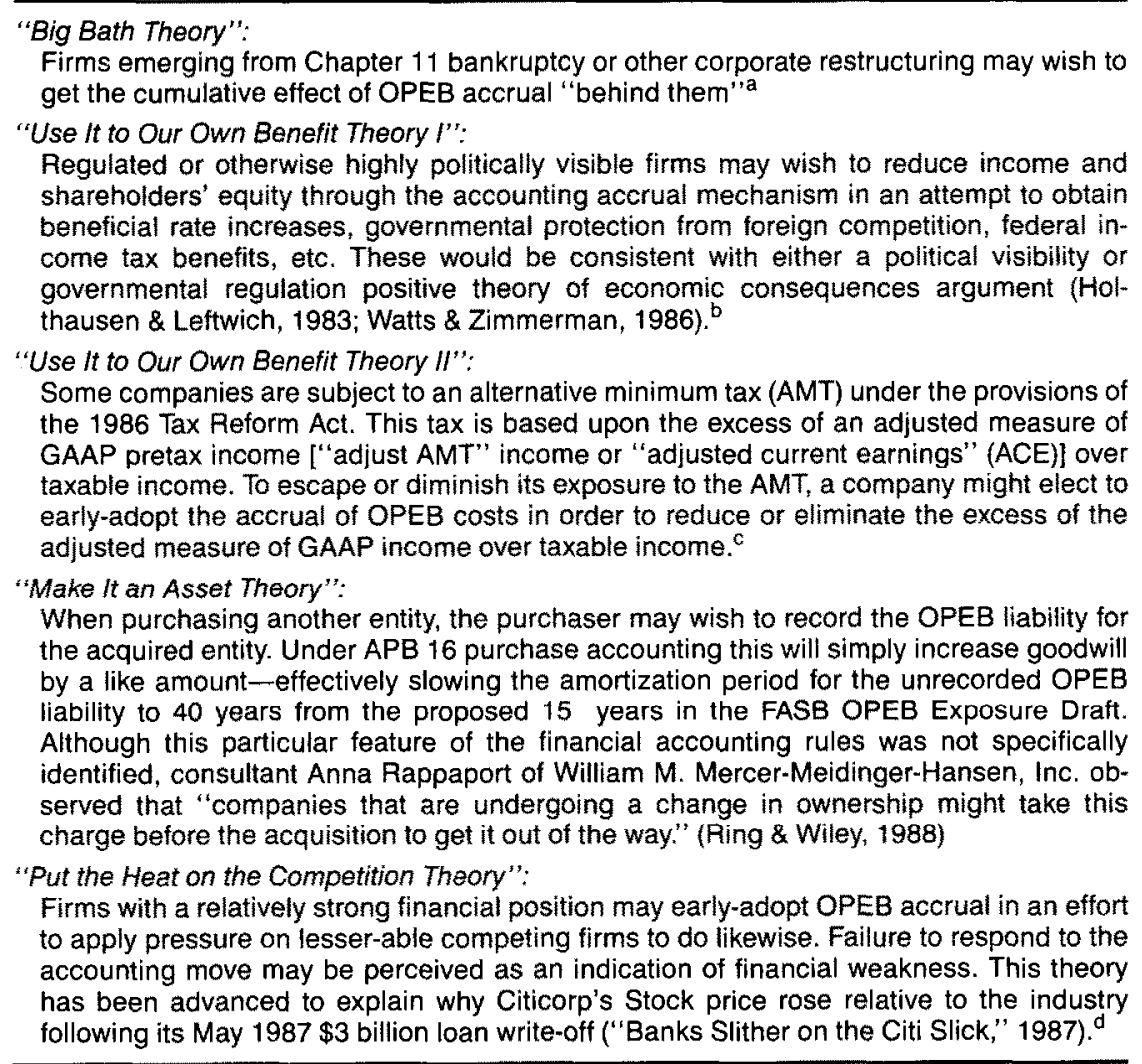

${ }^{a}$ As examples, T - LTV Corporation recorded a $\$ 2.3$ billion charge in September 1988 and Wheeling-Pittsburgh Steel Corporation recognized a $\$ 150$ million charge in 1987 for accrued OPEB costs.

${ }^{b}$ As an example. The Southern Company, an Atlanta-based system of electric utilities, began accruing OPEB life and health costs in 1987 for all of its systems subsidiaries except Georgia Power. Southern's footnote describing the accounting change reported that the $\$ 14.3$ million of additional charges had an immaterial effect on net income because most of the expense was recognized in the ratemaking process. Moreover, consistent with the regulatory treatment agreed to in its 1987 retail rate proceeding, Georgia Power (the one subsidiary not making the switch to accrual accounting for financial reporting purposes) must recognize such costs on the cash basis for rate proceedings purposes.

"This so-called book versus tax provision of the AMT provides incentives for some companies to self-select financial reporting practices in an effort to manage the overall tax liability. This potential impact of the tax law on financial reporting choices led representatives of both the FASB and the National Association of Accountants to publicly oppose this provision of the 1986 Tax Reform Act (Berton, 1986). The results of Gramlich (1989) and Burilovich (1990) suggest that overall GAAP accruals are responsive to the company's exposure to AMT.

'A possible example of this theory is General Mills' fiscal vear 1989 adoption of OPEB accrual accounting. Earnings per share in 1989 were $\$ 5.06$-after the cumulative and current year's effects of the OPEB accounting changes that were in excess of $\$ .90$ per share. Earnings per share for the two proceding years were $\$ 3.25$ and $\$ 2.50$. Thus, OPEB accrual was adopted in a year of relatively strong financial performance. 
of the CPA exam and leading financial accounting textbooks (Zeff, 1989). Several questions call on the student to assess the economic consequences of financial accounting data (Holthausen \& Leftwich, 1983; Watts \& Zimmerman, 1986) - a crucial element of a decision-oriented pedagogy that is often underemphasized in a pedagogy based on extant authoritative rules (Zeff, $1980,1982,1988) .^{10}$

- Obtain a copy of the annual report of a public entity with OPEB coverage for its employees. From the required disclosures under SFAS No. 81 estimate the off-balance sheet liability for OPEB costs. What key assumptions did you need to make and what additional information would you have wanted in order to make a more refined estimate? What is your impression of the adequacy of the current disclosure standards? How would the financial position and key financial ratios of the firm have been affected had the FASB adopted the proposed OPEB accounting rules 15 years ago? Are there any existing debt covenants disclosed in the company's 10-K (e.g., dividend payout ratios, tangible net worth, etc.) that would be affected? Compare your results with those obtained by your classmates for other firms. Can you draw any conclusions about cross-sectional differences in the off-balance sheet OPEB liability?

- Under Technical Bulletin 87-1 (FASB, 1987a) several companies have already elected to accrue OPEB costs. Using a database such as NAARS or reports in the financial press, locate such an example." Formulate a hypothesis about why the company would have begun accruing OPEB costs prior to an authoritative requirement. What other reasons might companies have to "early-adopt" OPEB accrual accounting?

- The FASB proposal to accrue OPEB costs, of course, creates no direct cash flow consequences to the affected firms. Nonetheless, in comments during public hearings before the FASB, Chrysler Corporation's Chief Financial Officer predicted that implementation of the new standard

\footnotetext{
10"Recommended solutions" to these questions are not offered in this article for two reasons. First, in many instances no single solution is "correct." Second, one objective of the cases is to raise issues and initiate class discussion about the ambiguities of the role of financial statement information in business and regulatory decisions. The case objectives do not focus on teaching a particular mechanical technique or on requiring students to respond with a particular set of previously learned information.

11In addition to those identified elsewhere in the paper, examples of firms voluntarily accruing OPEB costs include Batus, Inc., Bell South Corporation, The Boeing Company, The Brooklyn Union Gas Company, Centel, Deluxe Corporation, DPL, Inc., Energen Corporation, Florida Progress Corporation, Green Mountain Power Corporation, International Business Machines Corporation, Merck \& Company, Minnesota Mining and Manufacturing (3M), Overmyer Corporation, and Pacific Enterprises.
} 
would "unleash serious adverse social and economic effects" (Miller, 1989). These included increased prices and added inflationary pressures, lower incentives for capital and job formation, increased foreign ownership of the U.S. industrial base, increased outsourcing of operations with fewer full-time employees, and an increased burden on the government for health care coverage in a time of budget deficit and Social Security concerns. Given the lack of any direct cash flow consequences, what might be the indirect consequences of the proposed standards that would contribute to these predicted "serious adverse social and economic effects?"

- One company has defended pay-as-you-go accounting by stating:

- We have evaluated our ongoing expense based on our belief that the benefit is discretionary in nature and that pay-as-you-go accounting is appropriate under these circumstances. We are currently expensing on this basis and the amount is not material. However, it should be noted that if we continue our current programs, the ultimate liability is significant. . . Because of the fact that these benefits are not vested for either active employees or retirees, and can be revoked or amended from time to time, we do not feel it is appropriate to either record these liabilities or to disclose them in a footnote. (Coopers \& Lybrand and Hewitt Associates, 1985, p. 92)

Are the company's arguments accurate? Should the proposed requirement for companies to accrue costs vary according to the employer's ability to terminate future benefits? Suppose the respondent is correct in asserting that his company has the legal right to terminate the benefits. Would accrual accounting be inappropriate in this circumstance? Should the capital market impound an implied accrued liability into the valuation of the corporation's securities given the ability of managcment (or corporate "raiders") to terminate the plan in a corporate restructuring?

- Consider the following Wall Street Journal description of the OPEB proposal:

- The proposal . . . would require all companies to set up a reserve to cover these retirement costs. Companies would begin setting aside funds from the time an employee begins working and would add to the reserve during the time of employment until the employee becomes eligible for retirement benefits, generally at age 55 . (Berton, 1989b)

Is this representation accurate?

- Consider the comments of Raychem Corp.'s controller:

- Francis Lunger, vice president and controller of Raychem Corp., a Menlo Park, Calif.-based electronic parts maker with 4,500 employees, says that companies of Raychem's size aren't offering such benefits because they 
have been aware that the FASB was planning to issue the proposed accounting rule requiring a reserve for the benefits. Says Mr. Lunger, "How can we afford to offer such benefits when the minute we do, the FASB proposal would deliver a big hit to our profits?" (Berton, 1989b)

Is Mr. Lunger correct? Under the FASB proposal, what would be the effect on the financial statements for a company just initiating OPEB coverage? Contrast Mr. Lunger's comments with those of Congressman J. J. Pickle, chairman of the Oversight Subcommittee of the House Ways and Means Committee:

- In a way these questions seem odd to me, because these new accounting rules don't actually change the nature and the extent of the retiree health promises at all. The cost to business will be the same before and after FASB has acted. It seems to me that the new accounting rules are just forcing businesses to publicly acknowledge their existing commitments. ... If offering retiree health benefits was good company policy in the first place, it seems unlikely that properly accounting for them will make them unattractive. It may be that some companies will decide to cut these benefits. Is it a bad result for a business to decide that it cannot afford a benefit, and to cut back now rather than waiting until bankruptcy forces the issue? I think not. It is much better to know you are poor, than to live like a king in a fool's paradise. (Scott \& Upton, 1988)

How does the FASB proposal affect the affordability of OPEBs? Are there any potential indirect economic consequences from the proposed standard which have not been considered by Congressman Pickle? Should the FASB consider the impact of the proposed standard on employers' willingness to offer retiree medical care coverage?

- Lee Seidler, a senior managing director at Bear, Stearns \& Co.:

- No one's been right about guessing health care costs even one year out, let alone decades. So why slam it into the balance sheet? (Norman, 1988)

\section{Diana Scott, FASB OPEB Project Manager:}

- Any estimate has to be more reliable than zero. (Shalowitz, 1988)

With whom do you agree, and why?

- The FASB's proposed accrual accounting for OPEB costs has been criticized for introducing "cxcessive volatility" into the financial statements. Define "excess volatility." What other transactions and economic events have the potential for introducing volatility into the financial statements and what mechanisms have been adopted in various accounting standards to deal with "excessive volatility?" (e.g., Extraordinary gains and losses, employer accounting for defined benefit pension plans, foreign currency translations and fluctuations in the market value of investments in long-term marketable equity securities, misestima- 
tions in the accounting of a long-term asset or liability, and "lock-in" of assumptions in the life insurance industry in accounting for benefit reserves and deferred policy acquisition costs.)

- Recently, it has been increasingly recognized that U.S. firms operate in a "global economy." International aspects of the current business environment include intense competition with foreign firms, attempts by U.S. firms to establish markets in other countries, and the increased phenomenon of foreign ownership of previously U.S.-owned corporations. What impact might the OPEB crisis and the proposed accounting standards have on U.S. firms operating in a global economy?

- Creation of a government-sponsored entity to "insure" the unfunded OPEB liabilities of U.S. firms has been proposed. What entities or government agencies currently exist that serve an analogous function for other parts of the economy? ${ }^{12}$ What difficulties might arise from such legislation? If such an entity existed, would this make accrual accounting for OPEB costs less appropriate? How might the existence of such an entity affect the capital market's valuation of the securities of a firm with unfunded OPEB obligations?

- The FASB Conceptual Framework for financial reporting identifies "verifiability," "neutrality," "timeliness," and "predictive value" as desirable characteristics of financial accounting information (FASB, 1980). In what ways are these normative criteria useful in establishing authoritative guidance for OPEB accounting? Are there other basic concepts of accounting "theory" which are relevant to the OPEB issue?

- The FASB Conceptual Framework for financial reporting (FASB, 1985b) defines a liability as a "probable future sacrifice of economic benefits arising from present obligations of a particular entity to transfer assets or provide services to other entities in the future as a result of past transactions or events." Using this definition, what are the arguments for and against requiring OPEB accrual?

\section{SUMMARY}

Financial accounting educators have been widely criticized for excessively emphasizing authoritative rules and mechanical techniques underlying financial statement preparation. A user-oriented pedagogy would focus on the economic consequences of financial accounting choices, the role of accounting information within an economic context, and conceptual elements of authoritatively unresolved emerging issues.

Pedagogic concentration on extant authoritative pronouncements is illustrated by the lack of coverage of employer accounting for OPEBs. Despite

12Examples include the PBGC, FSLIC, FDIC, and State Insurance Insolvency Funds. 
its decade-long emergence as one of the most contentious issues facing both the FASB and numerous other political and economic agents and despite extensive reporting of the issue in the financial press, coverage of the topic in current editions of leading intermediate financial accounting textbooks ranges from scant to nil.

This article illustrates the treatment of a financial accounting topic from the decision-oriented perspective. An overview of the current economic, legal, and accounting issues surrounding OPEBs is provided as a source for relevant material useful in integrating the topic into the accounting curriculum. The background data is followed by speculation on future developments and a series of decision-oriented, analytical, and conceptually motivated cases and topics for class discussion.

\section{REFERENCES}

American Accounting Association (AAA), Committee on the Future Structure, Content and Scope of Accounting Education (The Bedford Committee) (1986). Future accounting education: Preparing for the expanding profession. Issues in Accounting Education, Spring, 168-195.

Banks slither on the Citi slick (1987). The Economist, May $30,75$.

Bazzle, K. (1989). Funding postemployment benefits. Management Accounting, April, 27-29.

Berton, L. (1986). Tax proposal could create problem over profit reported to shareholders. Wall Street Journal, May 20, 4.

Berton, L. (1988). FASB plan would make firms deduct billions for potential retiree benefits. Wall Street Journal, August 17, 3.

Berton, L. (1989a). S\&P will ignore proposed FASB rule raising firms' deductions for retirees. Wall Street Journal, September 5, B-12.

Berton, L. (1989b). FASB rule on retirees to cause furor. Wall Street Journal, February 9, A2.

Birnbaum, J. (1989). Shift in funding of pension plans mulled in house. Wall Street Journal, June 21, A2.

Brostoff, S. (1989). Congress gets retiree health benefits bill. National Underwriter-Life \& Health/Financial Services Edition, April 24, 2 and 5.

Burilovich, L. (1990). GAAP elasticities in the life insurance industry: The effect of tax law changes on the accounting behavior of mutual and stock life insurance companies, unpublished Ph.D. dissertation, University of Michigan, Ann Arbor.

Chasteen, L., Flaherty, R., \& O'Connor, M. (1989). Intermediate accounting. New York: Random House.

Cheney, G. (1989). OPEB impact study. Journal of Accountancy, August, 15-18.

Coopers \& Lybrand (1989). Retiree health benefits: Field test of the FASB proposal. Morristown, NJ: Financial Executives Research Foundation (FERF).

Coopers \& Lybrand \& Hewitt Associates (1985). Non-pension benefits for retired employees: Study of benefits and accounting practices. Morristown, NJ: FERF.

Corporate liabilities for retiree health benefits (1988). CPA Magazine, May, 6-8.

Courtis, J. (1987). Putting the cart before the horse. Journal of Accounting Education, Spring, 139-144.

Courts look to reasonable behavior in denial cases (1989). Employee Benefits Plan Review, February, 28-50.

Cron, W., Kintzele, M. \& Kintzele, P. (1988). Disclosure of postretirement benefits. The Michigan CPA, Winter, 50 and 52. 
DH\&S proposes fresh start for postretirement benefits accounting (1989). DH\&S Review, October 23.

DiBlase, D. (1989). Ameritech VEBA pre-funds retiree care. Business Insurance, February 27, 3-4.

Financial Accounting Standards Board (FASB) (1980). FASB statement of financial accounting concepts no. 2: Qualitative characteristics of accounting information. Stamford, CT: FASB.

Financial Accounting Standards Board (FASB) (1981). Discussion memorandum: An analysis of issues related to employers' accounting for pensions and other postemployment benefits. Stamford, CT: FASB.

Financial Accounting Standards Board (FASB) (1982). Preliminary views of the Financial Accounting Standards Board on major issues related to employers' accounting for pensions and other postemployment benefits. Stamford, CT: FASB.

Financial Accounting Standards Board (FASB) (1983). Discussion memorandum: An analysis of additional issues related to employers' accounting for pensions and other postemployment benefits. Stamford, CT: FASB.

Financial Accounting Standards Board (FASB) (1984). Statement of Financial Accounting Standards no. 81: Disclosure of postretirement health care and life insurance benefits. Stamford, CT: FASB.

Financial Accounting Standards Board (FASB) (1985a). Statement of Financial Accounting Standards no. 87: Employers' accounting for pensions. Stamford, CT: FASB.

Financial Accounting Standards Board (FASB) (1985b). FASB statement of financial accounting concepts no. 6: Elements of financial statements. Stamford, CT: FASB.

Financial Accounting Standards Board (FASB) (1987a). FASB technical bulletin 87-1: Accounting for a change in method of accounting for certain postretirement benefits. Stamford, CT: FASB.

Financial Accounting Standards Board (FASB) (1987b). Statement of Financial Accounting Standards no. 96: Accounting for income taxes. Stamford, CT: FASB.

Financial Accounting Standards Board (FASB) (1989). Exposure draft: Employers' accounting for postretirement benefits other than pensions. Stamford, CT: FASB.

Fluhr, H. (1989). Early retirement programs carry benefits, pitfalls for U.S. companies. Pension World, February, 34-37.

Freudenheim, M. (1988). Costly accounting change planned. The New York Times, September 15, D1 and D6.

Gewirtz, P., Green, M., \& Napoli, Jr., W. (1982). The unexpected benefit obligations. Financial Executive, January, 11-15.

Gramlich, J. (1989). The effect of the alternative minimum tax on accounting accruals, unpublished Ph.D. dissertation, University of Missouri, Columbia.

Greene, M. (1989). How to prefund medical benefits. Pension World, July, 46-47.

Greenwald, M. (1989). Bad news for the baby boom. American Demographics, February, 3437.

Holthausen, R., \& Leftwich, R. (1983). The economic consequences of accounting choice. Journal of Accounting and Economics, August, 77-117.

Inman, B., Wenzler, A., \& Wickert, P. (1989). Square pegs in round holes: Are accounting students well-suited to today's accounting profession? Issues in Accounting Education, Spring, 29-47.

Jereski, L. (1987). The silent killer. Forbes, February 23, 112.

Kieso, D., \& Wcygandt, J. (1989). Intermediate accounting. New York: John Wiley \& Sons.

Kullberg, D., Gladstone, W., Scanlon, P., Cook, J. M., Groves, R., Horner, L., O’Malley, S., \& Kangas, E. (1989). Perspectives on education: Capabilities for success in the accounting profession.

Miller, Jr., R. S. (1989). Statement to the FASB, November 3. 
Miller, S. (1988). An actuary's view. Journal of Accountancy, November, 30.

Mosich, A. (1989). Intermediate accounting. New York: McGraw-Hill Book Company.

Ness, I. (1989). Critics of new FASB rule predict benefit cutbacks. National Underwriter-Life \& Health/Financial Services Edition, February 20, 2 and 27.

Nikolai, L., \& Bazley, J. (1988). Intermediate accounting. Boston: PWS-Kent Publishing Company.

Norman, J. (1988). First thing we do is kill all the accountants. Business Week, September 12, 94-95.

Ostroff, J. (1989). An aging market: How business can prosper. American Demographics, May, 26-33 and 58-89.

Parker, M. (1988). Post-retirement care crisis: Firms try to assess impact of proposal. Pensions $\&$ Investment Age, September 5, 3 and 61 .

Ring, T., \& Wiley, C. (1988). Few to imitate LTV's accounting move. Business Insurance, December 5,36 .

Rudin, B. (1988). Post-retirement care crisis: FASB prescription may be a painful one. Pensions \& Investment Age, September 5, 3 and 60-61.

Schellhardt, T. (1989). Talking tactics. Wall Street Journal, December 8, R14.

Schmitt, R. (1988). Retirees fight cuts in health benefits: Firms' rights to alter rules aren't clear. Wall Street Journal, December 8.

Scott, D., \& Upton, Jr., W. (1988). Postretirement benefits other than pensions. Highlights of Financial Reporting Issues, December, Stamford, CT: FASB.

Shalowitz, D. (1988). FASB official defends retiree health proposal. Business Insurance, November 14,40 .

Subotnik, D. (1987). What accounting can learn from legal education. Issues in Accounting Education, Fall, 313-324.

Taplin, P. (1988). Spencer survey details cost of retiree coverages. Employee Benefit Plan Review, September, 10-12.

U.S. Department of Labor, Bureau of Labor Statistics (1989). CPI detailed report, June.

Watts, R., \& Zimmerman, J. (1986). Positive accounting theory. Englewood Cliffs, NJ: Prentice-Hall.

Welsch, G., \& Zlatkovich, C. (1989). Intermediate accounting. Homewood, IL: Irwin.

Williams, F. (1989a). Asset shift for health plans eyed. Pension \& Investment Age, January 9, 2 and 29.

Williams, F. (1989b). FASB motion tested: Costs rise, income drops. Pension \& Investment Age, June 28, 3.

Williams, J., Stanga, K., \& Holder, W. (1989). Intermediate accounting. New York: Harcourt Brace Jovanovich.

Wright, D. (1990). Voluntary accrual of other postemployment benefits, unpublished manuscript, University of Michigan, Ann Arbor.

Zeff, S. (1980). "Intermediate" and "advanced" accounting: The role of "economic consequences." The Accounting Review, October, 658-663.

Zeff, S. (1982). Towards a fundamental rethinking of the role of the "intermediate" course in the accounting curriculum, in D. L. Jensen, Ed., The impact of rule-making on intermediate financial accounting textbooks. Columbus, $\mathrm{OH}$ : College of Administrative Science, The Ohio State University, 33-51.

Zeff, S. (1988). Economic consequences in intermediate textbooks: A review after eight years. Issues in Accounting Education, Fall, 433-444.

Zeff, S. (1989). Does accounting belong in the university curriculum? Issues in Accounting Education, Spring, 203-209. 